\title{
The Impact of Informal Education Programs on the Out- of-School Syrian Refugee Children in Child-Family Centers (CFCs) in Jordan
}

\author{
Rami Inkheili, (MA) \\ University of Jordan, Jordan
}

doi: 10.19044/esj.2017.v13n4p182 URL:http://dx.doi.org/10.19044/esj.2017.v13n4p182

\begin{abstract}
The significance of this paper lies in shedding lights on the importance of informal education programs as catch up programs to educate those who didn't have the opportunity to be in schools for different reasons and bridge the gap between them and their peers in schools. Although the study will show how powerful this tool is, it is also worth mentioning that more efforts should be done to enroll those children in public schools and provide them with equal access to the formal education system. This study used pre and post tests that are designed upon the expected learning outcomes from the literacy and numeracy materials prepared by the technical team at Save the Children International. The designed materials, in order to be compliant with the advancement of students in the formal education system were based on the national learning outcomes set by the Ministry of Education in Jordan. The results of the study were excellent enough to show the positive impact of the program as 100 percent of the population scored the passing score in the posttest compared to the zero percent passing the pretest in both literacy and numeracy classes. On the other hand, the study also shows how deprived Syrian children are as a result of the bloody war that harvests not only their souls, but also their future. Finally, it is also worth mentioning that the study also speaks of the pressure on Jordan's formal education system and the need to support the Ministry of Education meeting the urgent demands of all students nationwide.
\end{abstract}

Keywords: Informal education, drop-outs, Child-family centers, literacy, numeracy

\section{Introduction}

This paper tries to highlight the importance of the informal education programs (provided to out of school Syrian refugee children in Jordan) in 
equipping them with the basic skills in Arabic language and maths to cope with their peers in schools, and bridge the gap between them.

The study used both descriptive and quantitative approaches in presenting the subject. It started by giving a background of the Syrian crisis since its outbreak in 2011, then mentioned some facts about the Syrian influx to Jordan providing some published data from both the UNHCR and the Jordan Government that show a more than two times difference in numbers (around 600,000 registered in the UNHCR records and 1.3 million according to the Department of Statistics DOS in Jordan).

After that, the study provided some stats about the educational status of Syrian refugees showing that around 115,000 are out of school for many reasons, violence and child labor as examples. It also outlined some examples of how the refugee influx put pressure on the public resources and services, schools were a clear example of this. As this attracted the attention of INGOs to support the Ministry of Education in its struggle to integrate all children in schools, the need for supplementary education services beside the formal one provided by the state was urgent and demanding, and from this point the informal education mode was put into action. In the following section, different modes of education were introduced and the context of applying informal education programs in Jordan through the interventions provided by Save the Children International was set. This was introduced by giving a historical brief of SCI informal education adopted materials that goes in line with the Ministry of Education curricula and builds on it.

The study finally ended up with measuring the impact of SCI informal education programs provided to "drop out" Syrian children in one host community center operating by SCI. The results were achieved through studying a sample of 60 children, from which 30 attended literacy classes and 30 attended numeracy classes. The study consisted of the application of pre and posttests that measure the basic Arabic literacy and numeracy skills before and after the program.

The significance of this paper lies in shedding lights on the importance of such interventions to educate those who didn't have the opportunity to be in schools for different reasons. As the results were impressive enough to evaluate the importance of the program, it's also worth mentioning that the concerned parties should take into consideration that those children have suffered enough and it's the responsibility of all to help them overcome their grief and give them at least equal access to the quality education they deserve by supporting the community engagement in the process and support the Ministry of Education improving the conditions of the education system overall. 


\section{Syria Crisis: A Background}

Pro-democracy protests started in March 2011 in the city of Deraa after the arrest and torture of some teenagers who painted anti-regime slogans on a school wall. After security forces opened fire on demonstrators, killing several, more took to the streets.

The unrest triggered nationwide protests demanding President Assad's resignation. The government's use of force to crush the opposition merely hardened the protesters' resolve. By July 2011, hundreds of thousands were taking to the streets across the country. Opposition supporters eventually began to take up arms, first to defend themselves and later to expel security forces from their local areas. ${ }^{62}$

Violence since then had escalated and took the form of armed conflict. The opposition arranged their lines and formed what was later called the Free Syrian Army and then civil war began initially between both armies, the formal regime army and the free army. Rebel brigades were formed to battle government forces for control of cities, towns and the countryside. Fighting reached the capital Damascus and the second city of Aleppo in 2012. 63

The situation got more complicated afterwards, Al Qaida along with other Islamic Jihadists entered the war and as a result Iran and Hezbollah also and finally Russia became part of this war. "It's partly a civil war of government against people; partly a religious war pitting Assad's ${ }^{64}$ minority Alawite sect, aligned with Shiite fighters from Iran and Hezbollah in Lebanon, against Sunni rebel groups; and increasingly a proxy war featuring Russia and Iran against the United States and its allies.” 65

After the rise of ISIS, the fighting sides became many and the civil war also extended to the Islamic Jihadist themselves and the considered moderate wings of Islamic militia, ISIS and Al Qaida entered a war with each other while on the same time fighting the regime, Hezbollah and Iranian militia. At this point, an Arabic-American-European alliance also entered the war to fight and limits the huge expansion of ISIS in the region, and finally, the Russian military intervention took the war to another dimension that helped maintaining the current regime, hence the toll of dead and injured significantly mounted amongst innocent civilians.

This ugly war has resulted in some shocking numbers that puts Syria crisis on top of all human crisis after World War II. According to the Syrian Center for Policy research, 470,000 were killed in this brutal conflict until February 2016 and $45 \%$ of population are displaced. In average, $11.5 \%$ of

\footnotetext{
${ }^{62}$ Gilsinan, K. (October 29, 2015).

${ }^{63}$ Rodgers, L., Gritten, D., Offer J., \& Asare, P. (March 11, 2016).

${ }^{64}$ Syrian President, Bashar Al Assad.

${ }^{65}$ Gilsinan, K. (October 29, 2015).
} 
the country's population are either killed or injured. Additionally, the economic losses were estimated at \$ 225 billion. $^{66}$

\section{Syrian Refugees in Jordan: Education Obstacles}

According to the UNHCR, ${ }^{67}$ Jordan is hosting 637,638 registered Syrian refugees as of April 2016, 85\% of them are residing urban areas and $15 \%$ are in camps. ${ }^{68}$

On the other hand, the Jordan 2015 population and housing census results report (issued on early 2016) indicates that the number of Syrian refugees in Jordan is 1.3 million, which makes around $15 \%$ of the total population in Jordan, additionally, 34\% of those refugees live in Amman, $27 \%$ in the northern city of Irbid and the rest are distributed all over other governorates. 69

Ever since the Syrian refugee influx's pessure on the very limited resources of Jordan had grown bigger, education (which is one of the affected sectors) is the largest system that hosts and serves population in Jordan, either in the form of children benefitting from the services or employees getting paid for delivering those services.

As a person working in this sector and having regular contact with Ministry of Education officials and directorates, around 100 schools are now operating double shifts up to the date of this study because of having 327,710 children at the age of 17 and below in schools. ${ }^{70}$ This actually results in less quality education, shortage of teachers, pressure on schools infrastructure and more spending to meet the requirements of the new existing situation.

However, not all of Syrian children at school age are enrolled in schools, $115,000^{71}$ children are out of school and have no access to education systems in the country. This large number of drop-outs could be referred to different reasons, like, the cutout from school for more than one year either in their home country or in the host country because of war and having the status of a refugee, the lack of coping mechanisms for Syrian refugees with the host community members which leads to more isolation, the rejection of having refugees competing people inside the community on livelihood opportunities, violence against Syrian refugees inside public schools as reported by parents, the in ability to issue formal papers to attend schools and finally the reason that tops all others is having those children performing child labor activities to generate income for the family.

66 Black, I. (February 11, 2016).

67 United Nations High Commissioner for Refugees.

${ }^{68}$ UNHCR. (April, 2016). Jordan Factsheet.

${ }^{69}$ Department of Statistics. (2016).

${ }^{70}$ UNHCR. (March, 2016). Jordan Factsheet.

${ }^{71}$ UNHCR. (March, 2016). UNHCR Operational Update. 
All of the above mentioned contributed to the little or no access of those children to quality formal education systems.

\section{Informal Education: A Good Tool}

After the Syrian influx to Jordan, some working NGOs touched the need of having those children enrolled in an education system that suits snd supports them educationally cope with their peers in schools. The majority of those childrens' families reported that they would not get their children back to school for many reasons like having them work and generate income for the family, fear of violence against them, lack of formal documents that permit their entrance to schools or in many cases having female children being exposed to early marriage as they see there is no point in educating them from a traditional perspective.

Accordingly, in their struggle to get those children back to school, the need of the existence of a system that can incorporate the out of school children in their learning community is demanding and the best fit for that is the informal education system. As a starting point, we need to know what education modes do we have and what is the difference between them and how did Informal Education can be a helpful tool.

Coombs and Ahmad differenciate between three modes of education, Formal, Informal and Non-formal. "Formal education as used here is, of course, the highly institutionalized, chronologically graded and hierarchically structured "education system," spanning lower primary school and the upper reaches of the university" 72

"Informal education as used here is the lifelong process by which every person acquires and accumulates knowledge, skills, attitudes and insights from daily experiences and exposure to the environment-at home, at work, at play; from the example and attitudes of family and friends; from travel, reading newspapers and books; or by listening to the radio or viewing films or television. Generally, informal education is unorganized and often unsystematic; yet it accounts for the great bulk of any person's total lifetime learning-including that of even a highly "schooled" person."73

On the other hand, the authors defined the non-formal educations as being:

“.... any organized, systematic, educational activity carried on outside the framework of the formal system to provide selected types of learning to particular subgroups in the population, adults as well as children. Thus defined, non-formal education includes, for example, agricultural extension and farmer training programs, adult literacy programs,

${ }^{72}$ Coombs, P. H. \& Manzoor, A. (1980). 8.

${ }^{73}$ Ibid. 8. 
occupational skill training given outside the formal system, youth clubs with substantial educational purposes, and various community programs of instruction in health, nutrition, family planning, cooperatives, and the like." ${ }^{\text {74 }}$

The given definitions pretty much spot the differences between the three modes (systems) of education and let us know how and in which context they can be employed. In the case of Jordan, formal and Non-formal education modes were the best match for the case of drop-out Syrian children who are unable to be at school to continue their education and the international NGOs working in this field did some great job in integrating children in those education modes, however, the work would not be complete without having the community involved in these initiatives along with other important stakeholders like the Ministry of Education for instance to highlight the importance of education to children and help them be reintegrated in the formal education system.

\section{Save the Children Informal Education Interventions with Syrian Drop- Out Children}

As mentioned before, INGOs did a good job in integrating out of school children in informal and non-formal education systems, Save the Children International office in Jordan had an excellent contribution in this, either in the camps or in the host community, SCI implemented informal education initiatives for drop outs in the form of Literacy and Numeracy classes starting from the year 2013. It helped many children acquire the basic literacy and numeracy skills appropriate for their age and supported their reintegration in schools. Building on the Ministry of Education national learning outcomes, SCI had developed structured materials that meets the basic literacy and numeracy needs for the first three levels addressing an age group of 6 to 13 years old. This material was implemented in all areas of operation of SCI, North region, Center and South region and camps. It's being implemented until the date this essay was developed and the organization has recently developed new levels for older age groups.

To measure the impact of informal education programs implemented by SCI in Jordan, one of the programs implemented in host communities in Amman was chosen. This Pearson-funded program is an educational intervention for Syrian refugee children and parents in two host communities in the areas of Hai Nazzal and $\mathrm{Al}$ Ashrafeyeh ${ }^{75}$ providing literacy and numeracy classes for out of school children aged 6-13 Y/O, early childhood care and development program for children aged 5-6 Y/O and their parents

${ }^{74}$ Ibid. 8.

${ }^{75}$ Two highly populated areas to the east of Amman. 
along with community engagement activities to support the educational progress and learning of children.

\section{The Impact of Informal Education Programs Implemented By SCI on Syrian Drop-Out Children Aged 6-13 Years Old: Population, Methodology and Results}

The population of the study were 60 children divided on two groups exposed to informal education program in the Hai Nazzal center. The program lasts for 4 months period, through which the child will learn the skills that qualifies him or her to be on the same stand as his peers in schools. The literacy material covers the skills needed for three levels like, reading, comprehension, listening, writing of alphabets, words and sentences for higher levels. The numeracy material teaches the children the basic mathematical skills like numbers and basic mathematical calculation.

One of the two groups attended literacy sessions and the other attended numeracy classes, each group is basicly consisted of 30 children and all have attended a four-month accelerated learning program for the first level taht is taught by trained teachers. Given that the study measures the impact of a service on the benefeciaries, the application of a quantitative tool is necessary for such purposes, and this was accopmplished through pre and posttests specifically developed to evaluate the progress before and after the intervention.

The pre and posttests for the first level numeracy class mainly measures the child's ability to read the alphabets, match the words that start with the same alphabet, pronounce the alphabets, make words from scrambled aphabets and the other way around. The numeracy tests on the other hand measure the child's ability to count objects, distinguish between numbers between 1-9, write the subsequent of a given number between 1-9, write the previous of a given number between 1-9, distinguish between greater and less numbers between 1-9, arrange the numbers between 1-9 in descending and ascending order, additions of numbers between 1-9 and subtraction of numbers between 1-9. The learning outcomes of both tests are mainly based on the outcomes of the first grade national curriculum developed by the as the objective of this program is to help the children catch up what they have missed and enroll them in public schools.

The study sample are children attending the first level sessions of both programs (literacy and numeracy), the passing mark for both tests was $60 \%$. Two samples were choosen from both groups and the sample was randomly selected as one student out of three, I started with no. 3 to 6, 9, 12, etc.

The results of the postest showed huge improvement in the children level after the four-month program as the majority scored zero out of 100 . 
The two tables below show the improvement achieved after the program. Table 1 shows the results of the test for literacy classes and table no. 2 shows the results of the test for literacy classes.

\title{
LITERACY PROGRAM RESULTS
}

\author{
\&Before \&After
}

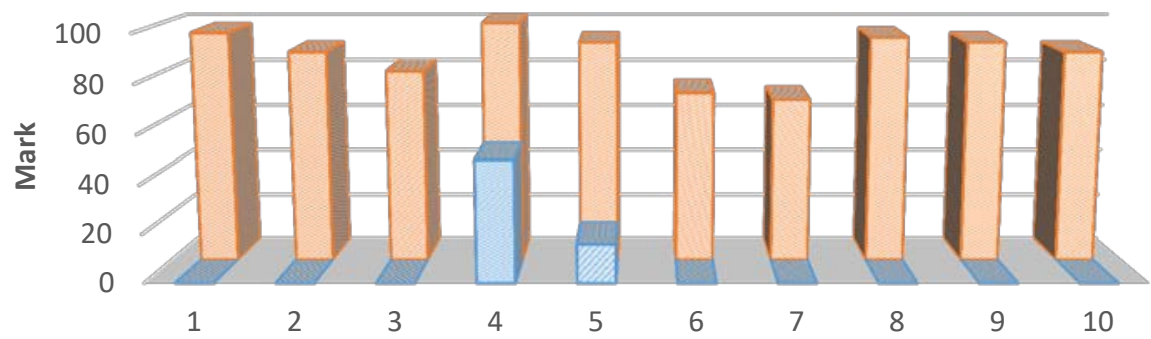

\section{Children Tested}

\begin{tabular}{|l|c|c|c|c|c|c|c|c|c|c|}
\cline { 2 - 13 } \multicolumn{1}{c|}{} & 1 & 2 & 3 & 4 & 5 & 6 & 7 & 8 & 9 & 10 \\
\hline B Before & 0 & 0 & 0 & 50 & 16 & 0 & 0 & 0 & 0 & 0 \\
\hline After & 96 & 88 & 80 & 100 & 92 & 71 & 68 & 94 & 92 & 88 \\
\hline
\end{tabular}

Table 1

We can see in the chart above the remarkable improvement took place here. Two out of ten children scored more than zero in the pretest, on the other hand, only two scored under 80 in the posttest, six scored from 80 to 98 and one scored a full mark. 


\section{NUMERACY PROGRAM RESULTS}

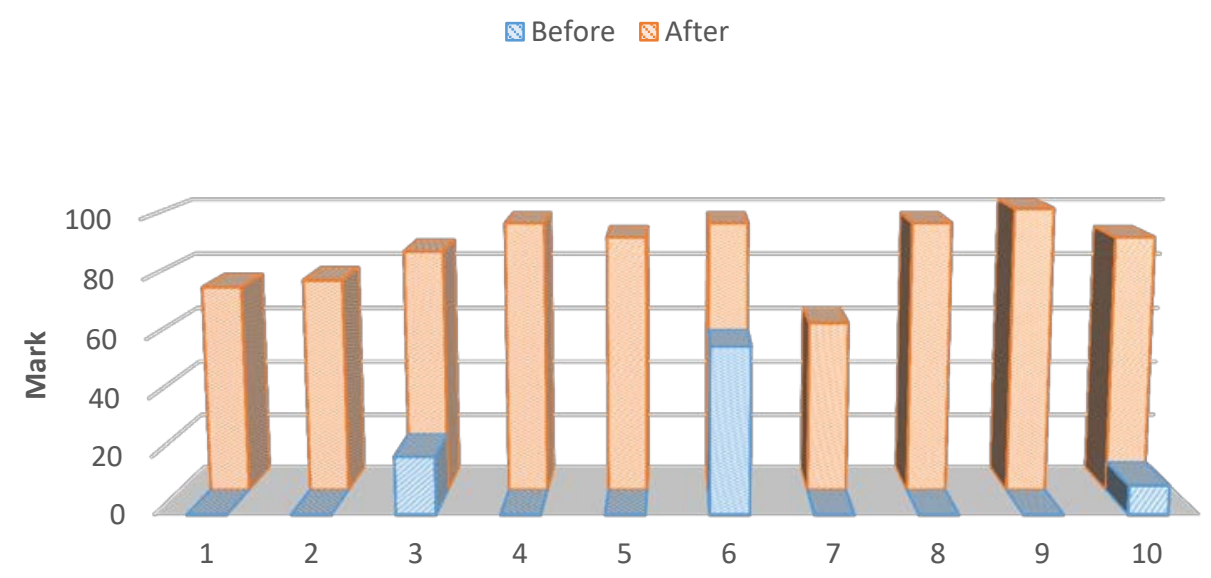

\begin{tabular}{|c|c|c|c|c|c|c|c|c|c|c|}
\hline & \multicolumn{10}{|c|}{ Children Tested } \\
\hline & 1 & 2 & 3 & 4 & 5 & 6 & 7 & 8 & 9 & 10 \\
\hline 圆 Before & 0 & 0 & 20 & 0 & 0 & 57,5 & 0 & 0 & 0 & 10 \\
\hline ه After & 72,5 & 75 & 85 & 95 & 90 & 95 & 60 & 95 & 100 & 90 \\
\hline
\end{tabular}

Table 2

In the numeracy program results reflected in table 2, three out of ten children scored above zero in the pre test, while in the posttest we can see that the improvement is remarkable as the ten children passed the test with $60 \%$ percent as the lowest mark and $100 \%$ as the highest. From another perspective, we can also notice that the improvement of skills in the numeracy program is a little lower than the literacy program, yet still high.

\section{Conclusion}

The Syrian crisis that started in 2011 had resulted in a lot of suffering to the people of Syria as 470,000 were reported killed because of this brutal multi facets war, the proxy and the civil war caused a flee of millions of Syrians to the neighboring countries to escape their lives from death. Jordan hosts nearly 1.3 million Syrian refugees in both camps and host communities causing some more pressure on the resources and services in all sectors. One of those sectors is education that operates double-shifts schools to cover the big numbers of Syrian children in need of education. However, the UNHCR reports show that there are about 115,000 Syrian children who are out of school and have no access to any kind of educational services for many 
reasons such as the lack of formal and security documents, violence against Syrian children in public schools and child labor.

The need for supportive solutions to those children is essential and INGOs started providing informal education services for those children. Save the Children International as being one of the leading international organizations provided this service to the out-of-school Syrian children all over Jordan. The sample studied from SCI centers were aged 6-13 years old children who didn't have access to public schools and had no or little basic literacy and numeracy skills. The results of the study and the progress made were impressive to the point that those programs are in a way or another equivalent to their counterparts in the formal education system but for sure not a replacement.

\section{References:}

1. Black, I. (February 11, 2016). Report on Syria conflict finds $11.5 \%$ of population killed or injured. The Guardian

2. Coombs, P. H. \& Manzoor, A. (1980). Attacking Rural Poverty: How Nonformal education Can Help. (3rd ed.). Baltimore: The Johns Hopkins University Press.

3. Department of Statistics. (2016). 2015 Population and Housing Census Main Results Report. Jordan: DOS

4. Gilsinan, K. (October 29, 2015). The Confused Person's Guide to The Syrian Civil War. The Atlantic

5. Rodgers, L., Gritten, D., Offer J., \& Asare, P. (March 11, 2016). Syria: The Story of the Conflict. BBC News

6. UNHCR. (April, 2016). Jordan Factsheet. Jordan: UNHCR Jordan Office http://data.unhcr.org/syrianrefugees/download.php?id=10732

7. UNHCR. (March, 2016). Jordan Factsheet. Jordan: UNHCR Jordan Office http://data.unhcr.org/syrianrefugees/download.php?id=10612

8. UNHCR. (March, 2016). UNHCR Operational Update. Jordan: UNHCR Jordan Office http://reliefweb.int/sites/reliefweb.int/files/resources/UNHCR\%20Jor dan\%20Operational\%20Update\%20March\%202016\%20FINAL.pdf 